\title{
Emerging global role of small lakes and ponds: little things mean a lot
}

\author{
John A. Downing* \\ Ecology, Evolution \& Organismal Biology, Iowa State University, Ames, IA, USA \\ * Corresponding author: downing@iastate.edu
}

Received: 6/10/09 Accepted: 18/10/09

\begin{abstract}
Emerging global role of small lakes and ponds: little things mean a lot

Until recently, small continental waters have been completely ignored in virtually all global processes and cycles. This has resulted from the neglect of these systems and processes by ecologists and the assumption that ecosystems with a small areal extent cannot play a major role in global processes. Recent inventories based on modern geographical and mathematical approaches have shown that continental waters occupy nearly twice as much area as was previously believed. Further, these inventories have shown that small lakes and ponds dominate the areal extent of continental waters, correcting a centurylong misconception that large lakes are most important. The global importance of any ecosystem type in a process or cycle is the product of the areal extent and the intensity of the process in those ecosystems. Several analyses have shown the disproportionately great intensity of many processes in small aquatic ecosystems, indicating that they play an unexpectedly major role in global cycles. Assessments of the global carbon cycle underscore the need for aquatic scientists to view their work on a global scale in order to respond to the Earth's most pressing environmental problems.
\end{abstract}

Key words: Ponds, lakes, global limnology, carbon, lake size, sequestration.

\section{RESUMEN}

La emergencia del papel global de los pequeños lagos y charcas: el gran significado de las pequeñas cosas

Hasta muy recientemente, las aguas continentales de pequeño volumen se han ignorado completamente en todos los procesos y ciclos globales. Esto ha sido el resultado de la poca consideración de estos ecosistemas y procesos por los ecólogos y de asumir que los ecosistemas que ocupan un área pequeña no juegan ningún papel importante en los procesos globales. Inventarios recientes basados en aproximaciones geográficas y matemáticas modernas indican que las aguas continentales ocupan casi el doble del área de lo que se creía anteriormente. Además, estos inventarios han mostrado que las charcas y lagunas de pequeñas dimensiones predominan en la extensión superficial de las aguas continentales, corrigiendo la concepción equivocada de todo un siglo de que los grandes lagos eran los más importantes. La importancia global de cualquier tipo de ecosistema en un proceso o ciclo es el producto de su superficie por la intensidad del proceso en el ecosistema. Diversos análisis han mostrado la intensidad desproporcionadamente grande de muchos procesos en los pequeños sistemas acuáticos, indicando su sorprendente papel primordial en los ciclos globales. Evaluaciones del ciclo global del carbono ponen de manifiesto la necesidad de que los ecólogos acuáticos tengan una visión de su trabajo a escala global, para poder responder a los problemas ambientales más preocupantes.

Palabras clave: Charcas, lagos, limnología global, tamaño de los lagos, secuestro de carbono.

\section{INTRODUCTION}

Ever since Halbfass (1914) and Thienemann's (1925) work cataloguing the lakes of the world, science has assumed that the world's large lakes cover the most area and therefore are the most important to study (Downing et al. 2006, Downing \& Duarte 2009). In spite of this long-standing 
error of scientific reasoning (Downing 2009), our common, human experiences tell us that small things in life, society, or nature can be more important than their sizes imply. For example, part of the title of this article ("Little things mean a lot...") comes from song lyrics by Edith Lindeman (no relation to Raymond) expressing that the tiny gestures people make have the most value. The $19^{\text {th }}$ Swiss philosopher and poet, Henri-Frédéric Amiel, suggested that "What we call little things are merely the causes of great things" (Amiel 1893). Bruce Fairchild Barton, the American publicist, politician, and author wrote, "Sometimes when I consider what tremendous consequences come from little things... I am tempted to think there are no little things" (Barton 1917). The $18^{\text {th }}$ century German scientist, satirist, and philosopher, Georg Christoph Lichtenberg, noted that "the tendency of people to consider small things as important has produced many great things" (Friederici 1978). We should not be misled by their small relative size into assuming that small lakes and ponds are unimportant. In A Case of Identity (Conan Doyle 1920), Sir Arthur Conan Doyle (speaking as Sherlock Holmes) suggested, "It has long been an axiom of mine that the little things are infinitely the most important." Human experience suggests that we should expect the small parts of aquatic ecosystems, e.g., small lakes, ponds, puddles, marshes, and streams, to be of disproportionately great importance in world cycles and processes.

\section{Lakes, especially small ones, are ignored globally}

Globally, lakes and ponds are generally ignored as being insignificant or are thought of only as reservoirs where water and materials are held for a short time before delivery to streams, rivers, and the oceans. Terrestrial ecologists, climatologists, and oceanographers tend to think of continental waters as "plumbing" that delivers or transports water, with little processing. Recently, this has been shown to be an incorrect assumption (Cole et al. 2007, Downing 2009, Tranvik et al. 2009). Further, scientists studying lentic waters have long known that they process glob-

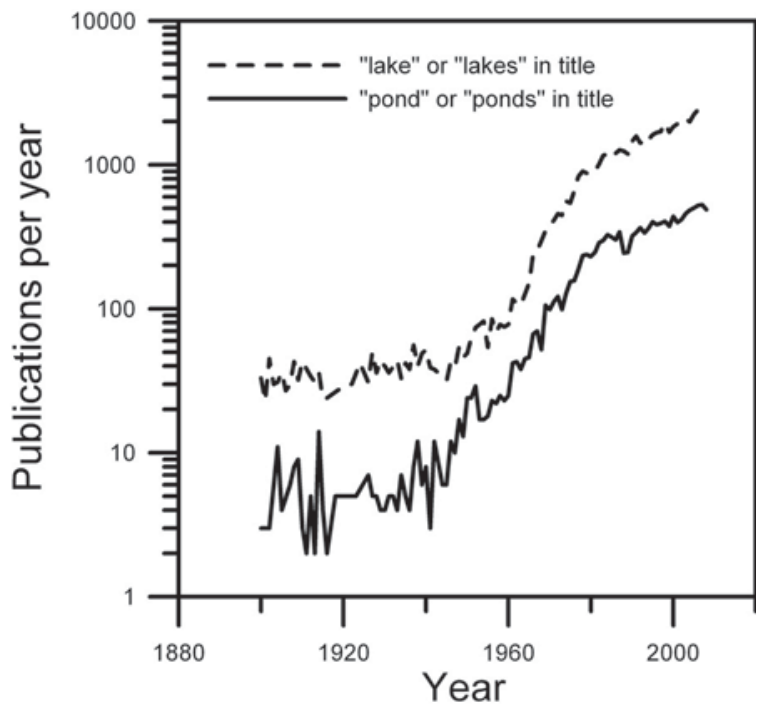

Figure 1. Frequency analysis of use of "lake" or "lakes" versus "pond" or "ponds" in the title of scientific publications indexed by the Web of Science over the last century. Absolute frequency is dependent on the literature indexed by Web of Science and the completeness of index coverage. Análisis de frecuencias de la utilización de la palabra "lake" o "lakes" versus "pond" o "ponds" en los títulos de las publicaciones científicas indexadas en la Web of Science durante el siglo pasado. Las frecuencias absolutas dependen de la bibliografía indexada y la cobertura de dicho índice.

ally important materials. The concepts of nutrient and material retention and spiraling have been rudiments of limnology for several decades.

The study of small aquatic systems has lagged behind larger-lake limnology over much of the past century. An analysis of publications on "ponds" versus "lakes" in the publications indexed by Web of Science (Fig. 1) suggests the bias of ecologists and limnologists toward studying larger water bodies as well as the differential rates of growth of publications in these areas (see also Oertli et al. 2009). This analysis shows that studies titled as pond studies constitute only about $25 \%$ of the aquatic publications indexed in any given year. Further, although the rate of growth in the publication of pond studies increased at an average $19 \%$ per year from 1940-1980, lake studies increased extremely rapidly during the boom years of eutrophication remediation. Publications entitled as pond or lake studies have decelerated in the past decade, with rates of growth in pond analyses decelerating more than those of lakes. 
Table 1. Analyses of global cycles and processes completely omitting any reference to ponds or small lakes. Análisis de ciclos y procesos globales omitiendo totalmente cualquier referencia a charcas o lagunas.

\begin{tabular}{ll}
\hline Cycle or budget & Reference \\
\hline Carbon & (Goody \& Walker 1972, Bolin 1983, Schimel et al. 1995, Intergovernmental Panel on Climate Change 2001, \\
Energy/Radiation & $($ Christopherson 1994, Kiehl \& Trenberth 1997, Hermann 2006) \\
Greenhouse gases & $\mathrm{CO}_{2}:$ (Thorneloe et al. 2002) \\
& $\mathrm{CH}_{4}:$ (Weissert 2000) \\
& $\mathrm{N}_{2} \mathrm{O}:$ (Seinfeld \& Pandis 1998) \\
Nitrogen & (Rosswall 1983, Chameides \& Perdue 1997, Bin-le et al. 2000, Roy et al. 2003, Raven et al. 2004) \\
Oxygen & $($ Cloud \& Gibor 1970, Goody \& Walker 1972, Walker 1980, Keeling et al. 1993) \\
Phosphorus & (Graham \& Duce 1979, Richey 1983, Lerman 1988) \\
Silicon & (Goody \& Walker 1972, Nelson et al. 1995, Tréguer et al. 1995) \\
Sulphur & (Freney et al. 1983, Raven et al. 2004) \\
Water & (Clarke 1991, Hinrichsen et al. 1998, Winter et al. 1998) \\
\hline
\end{tabular}

That small aquatic ecosystems are currently perceived as irrelevant to global problems is, however, undeniable. One needs only to look at schematic diagrams of various global material cycles to see that limnology and aquatic ecology have been left behind. Nowhere is this more obvious than in global analyses of the carbon cycle (e.g., Schimel et al. 1995). All continental waters are frequently absent from these global views. The carbon they store and any processing of this material they do (e.g., burial, emission) are completely omitted. Small, continental aquatic ecosystems are ignored in virtually all global views and processes (Table 1).

\section{Lakes, ponds, rivers, and streams are of global importance}

Although they have been ignored, limnologists know that our systems are significant in global cycles. Nowhere is failing to consider them more serious than in the global carbon budget. Accuracy of estimation of the global carbon budget is critical because it will determine how effectively society can respond to the challenge of global climate change.

A few years ago, some of us attempted to integrated fragmentary knowledge on the role of inland waters into the global Carbon (C) cycle
(Downing et al. 2006, Cole et al. 2007). The information available at the time indicated that, far from being neutral conduits of $\mathrm{C}$ from lands to the sea, inland waters process large amounts of carbon buried in freshwater ecosystems or degassed to the atmosphere. Since that time, we have learned that the first calculations underestimated the area covered by virtually every category of inland waters (Downing et al. 2006, Downing 2009, Downing \& Duarte 2009). Those estimates demonstrated that inland waters may process about $1 \mathrm{Pg} / \mathrm{y}$ (petagram/year) more C than was previously thought to be delivered to them. This was more than double the amount back-calculated as the landscape's contribution to rivers and the sea through the supposedly neutral conduit of inland waters. These numbers are being revised upward quite rapidly (e.g., Tranvik et al. 2009) and now show a very active processing of $\mathrm{C}$ by aquatic ecosystems (Fig. 2). Traditional analyses have calculated the loss of $\mathrm{C}$ from the landscape simply as the amount delivered to the sea by rivers but these calculations have ignored the role of inland waters in emitting and burying $\mathrm{C}$.

Cole et al.'s (2007) calculations are being rapidly revised upward, underscoring the need for limnologists to engage in global limnology 

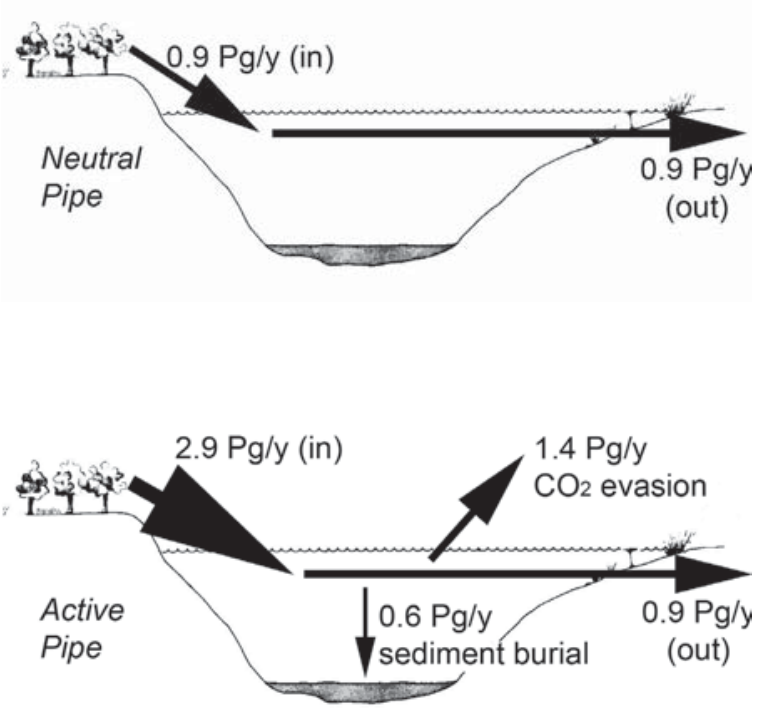

Figure 2. Illustration of the quantitative and qualitative differences between the "neutral pipe" model suggesting the inland waters transport carbon without processing it, and the "active pipe" model (Cole et al. 2007) in which preliminary estimates of the global burial of $\mathrm{C}$ by aquatic ecosystems and the evasion of $\mathrm{CO}_{2}$ by aquatic ecosystems is admitted. The original view of these models has been revised to reflect more recent data (Tranvik et al. 2009). This revision suggested that the large burial and evasion of carbon by aquatic ecosystems requires that export from land is almost three-times greater than previously believed. $\left(\mathrm{Pg} / \mathrm{y}=10^{15}\right.$ grams/year). Esquema de las diferencias cuantitativas y cualitativas entre el modelo de "conducto neutro" en donde las aguas continentales transportan el carbono sin procesarlo y el modelo de "conducto activo" (Cole et al. 2007) en el cual se admite el entierro global de C y la liberación de $\mathrm{CO}_{2}$ por los ecosistemas acuáticos. El esquema original de estos modelos se ha revisado para reflejar los datos más recientes (Tranvik et al. 2009). Esta revisión sugiere que el prominente entierro y liberación de C por los ecosistemas acuáticos, requiere que se exporte desde las zonas terrestres una cantidad casi tres veces mayor de lo que anteriormente se creía.

(Downing 2009). This lacuna is very obvious considering the under-emphasis of the global role of small aquatic ecosystems. The former view that Earth's important compartments are ocean, atmosphere, and land, connected together by the assumed neutral pipes and conduits provided by large lakes and rivers was a major error. An accurate understanding of global cycles requires seeing the biosphere as a network of inter-connected metabolically active sites, including small lakes and ponds.

\section{Why might small lakes and ponds be very important?}

It has recently been suggested that the global importance of any set of ecosystems is determined by the product of the amount of the biosphere they constitute and the intensity of the process of interest within them (Downing 2009). Downing (2009) also explored ways of "scaling-up" measurements made in small lakes and ponds for evaluating their global role. The global role of small lakes and ponds has been doubly missed in the past because the spatial extent of lakes has been underestimated as well as the fraction of the world's lakes that are small (Lehner \& Döll 2004, Downing et al. 2006).

An early inventory of the world's lakes was first published in 1914 (Halbfass 1914) and was expanded to include August Thienemann's analysis of the lakes of Europe (Thienemann 1925). At that time, Thienemann (1925) suggested that around 2.5 million $\mathrm{km}^{2}$ or about $1.8 \%$ of the land surface, is covered with lakes and ponds, and that global lake area is dominated by a few very large lakes (Downing 2009). This viewpoint was fundamentally unchanged for about 70 years (Schuiling 1977, Herdendorf 1984, Meybeck 1995, Kalff 2001) except that Robert Wetzel (1990) felt that the world's lake area is dominated by small lakes and ponds (Downing et al. 2006).

Lehner and Döll (2004) performed a full inventory of world lakes by using GIS of satellite imagery to count all of the world's moderately sized to large lakes, but could not count small lakes and ponds $\left(\leq 0.1 \mathrm{~km}^{2}\right)$. Their data suggested a Pareto distribution (Pareto 1897, Vidondo et al. 1997) that appears to fit lake-size distributions down to $0.001 \mathrm{~km}^{2}$ (Downing et al. 2006). A similar relationship was also found to fit the abundance and size-distribution of the world's constructed lakes and analyses of regional data showed that constructed farm ponds bore a consistent relationship to agricultural land area and precipitation (Downing et al. 2006). These results suggest that there are 304 million natural lakes in the world and they cover about 4.2 million $\mathrm{km}^{2}$. This area is nearly twice that assumed by several others (Schlesinger 1997, Kalff 2001, 


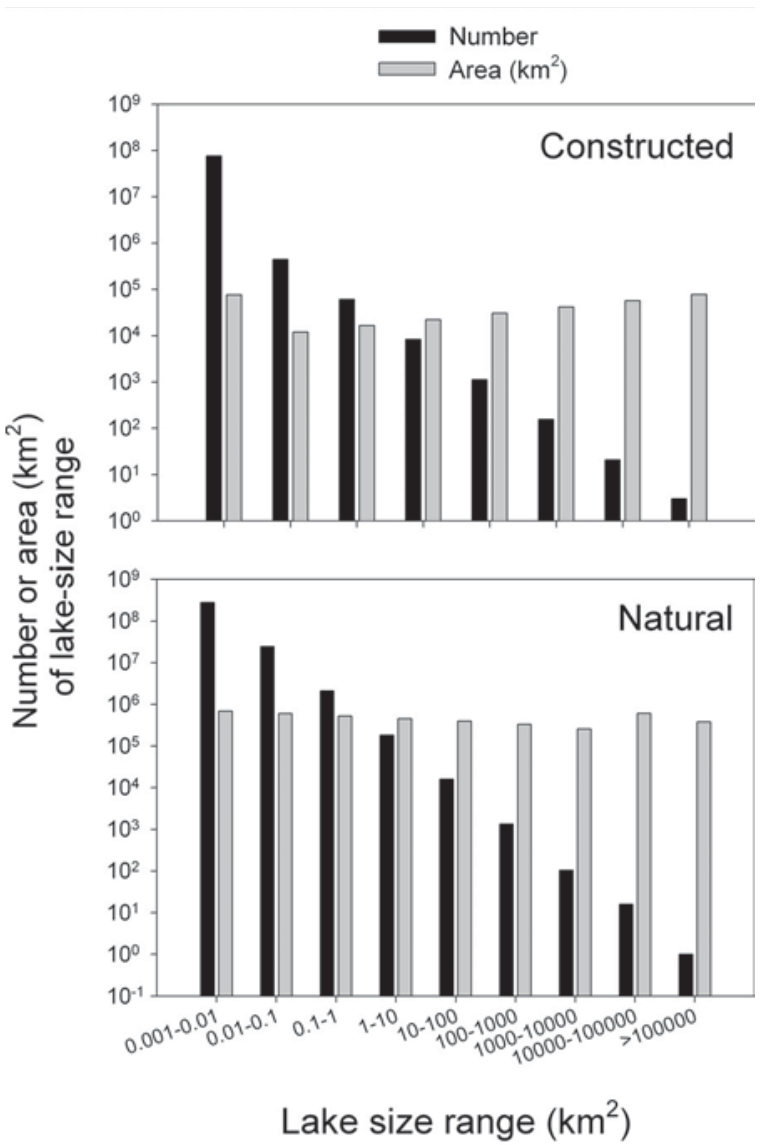

Figure 3. Global size distributions of numbers and land area covered by natural and constructed lakes. Data are re-plotted from the original publication (Downing et al. 2006). The figure shows that size distribution of natural lakes and constructed lakes are similar and that global lake area is dominated by small lakes, not large ones as $20^{\text {th }}$ century analyses suggested (Halbfass 1914, Thienemann 1925, Schuiling 1977, Herdendorf 1984, Meybeck 1995). Distribución global del número y superficie de los lagos construidos y naturales. Datos reproducidos de la publicación original (Downing et al. 2006). La figura muestra que el tamaño de los lagos naturales y los construidos es similar y que el área global está dominada por los lagos pequeños y no por los grandes como sugerían los análisis efectuados en el siglo XX.

Wetzel 2001, Shiklomanov \& Rodda 2003) and the area is more strongly dominated by small lakes and ponds (Fig. 3) than past analyses have suggested.

\section{How small are the smallest lakes and how long do they last?}

Many pond ecologists work on water bodies even smaller than the lowest interval on figure 3 . If one uses the Pareto distribution to project the number of water bodies on Earth in the range of $0.0001-0.001 \mathrm{~km}^{2}\left(100-1000 \mathrm{~m}^{2}\right)$, the result accentuates the dominance of small water bodies on continents. It is likely that there are about $3.2 \times 10^{9}$ natural ponds in this size-range and they have an area of around 0.8 billion $\mathrm{km}^{2}$. Whether these ecosystems are permanently aquatic or become semi-terrestrial at certain times of the year, or whether they wax and wane over the course of geological time is not fully known. Our ability to catalog and map small features is, as yet, new, and we will learn how these small landscape features contribute to the interface of terrestrial and aquatic ecology.

Most of the Pareto distributions we have analyzed (Downing et al. 2006) had some curvature toward the small sizes of lakes, implying that they had been underestimated in inventories, removed from the landscape through erosion, deposition, and landscape alteration, or both. It seems quite likely that the residence time of small water bodies on a landscape may be low enough that some small systems disappear over time or are replaced by processes of pond formation. Some may be essentially hydric soils for part of the year. Any alteration of the land surface, including the filling of depressions can result in new small depressions that accumulate water and generate an aquatic ecosystem.

The intensive activity of small aquatic ecosystems and their dimensions make them more dynamic in time than large water bodies. I know, for example, of many small ponds that I knew as a child that are no longer part of the aquatic landscape. Likewise, however, I know of many modern small ponds that did not exist a few decades ago. One can estimate the relationship between the sizes of lakes or ponds and their likely lifespans following some assumptions about dimensions and morphometry. If the mean depth $(\mathrm{m})$ of a lake is assumed to be $12.1 \sqrt{L^{\prime}}$, where $L^{\prime}$ is the average of effective length and breadth $(\mathrm{km})$ (Gorham 1958, Straškraba 1980), figure 4 shows the likely life-span of these lakes and ponds, assuming that lakes are elliptical in shape with length about double the breadth.

If sediment deposition is around $1 \mathrm{~mm} / \mathrm{y}$ then very small lakes and ponds $\left(<0.01 \mathrm{~km}^{2}\right)$ will 


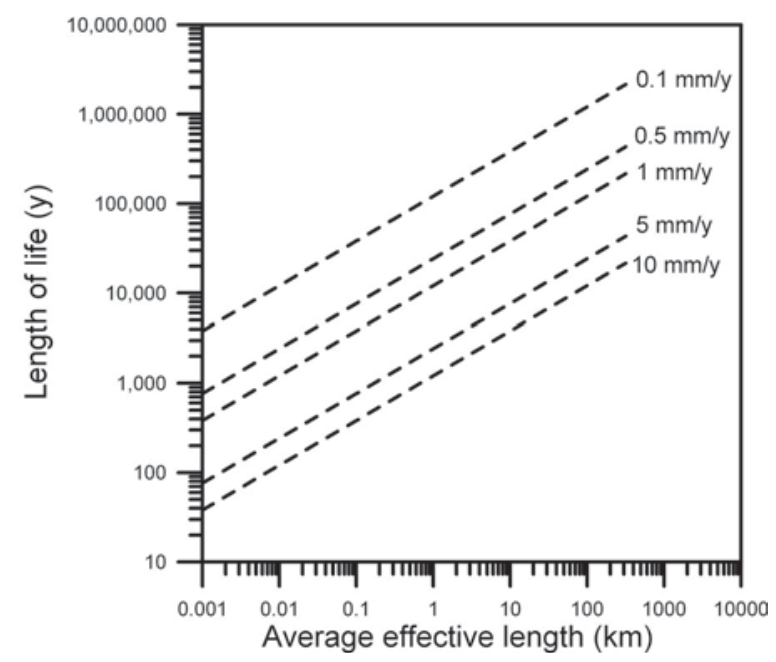

Figure 4. Potential life-time of aquatic ecosystems of a range of sizes. The calculations were based on assumed rates of sedimentation spanning the range of those observed in oligotrophic to eutrophic lakes and the assumptions that the mean depth (m) of a lake is around $12.1 \sqrt{\mathrm{L}^{\prime}}$, where $\mathrm{L}^{\prime}$ is the average of effective length and breadth (km) (Gorham 1958, Straškraba 1980), and length is approximately double the breadth. Duración potencial de los ecosistemas acuáticos de diferentes tamaños. Los cálculos se han basado en las diferentes tasas de sedimentación estimadas de las observadas en lagos, desde oligotróficos a eutróficos, y en el supuesto de que la profundidad media $(m)$ de un lago sería $12.1 \sqrt{L^{\prime}}$, en donde $L^{\prime}$ es la media de la longitud y anchura efectivas (Gorham 1958, Straškraba 1980), siendo la longitud aproximadamente el doble de la anchura.

have lifetimes of $<1000 \mathrm{y}$. In even more oligotrophic landscapes where sediment deposition rates are $<1 \mathrm{~mm} / \mathrm{y}$, small lakes and ponds might take $1000-10,000$ y to disappear. In highly erodible, nutrient-enriched environments, however, substantially sized small lakes and ponds may disappear in a few decades through filling and succession. This temporal dynamic is a unique feature of the limnology of small lakes and ponds and accentuates our need to understand their function as well as their succession and origination.

\section{Ponds and small lakes play an active global role}

The global importance of any ecosystem type is determined by the product of the aerial extent of that ecosystem across the Earth and the intensity of processes in them, relative to other ecosystem types (Downing 2009). Indeed, the global dominance of limnological processing only requires that these processes be more than 33-times greater (on an areal basis) in lakes than in terrestrial environments and more than 115-times greater than in the world's oceans. If globally important rates and processes are the same in small $\left(\leq 1 \mathrm{~km}^{2}\right)$ lakes and ponds as they are in larger ones, small lakes and ponds constitute at least a third of the processing by aquatic ecosystems on the planet (Fig. 3). For small lakes and ponds to dominate inland aquatic processing, rates and processes in small systems need only be double those seen in larger ones. Knowledge of the "intensity" of processes is an important need in order to participate in global science.

Many aquatic rates, processes, and quantities are more intense, complex, or abundant in ponds and small lakes than in larger lakes. The biotic complexity and richness of small aquatic systems is well-known. For example, macrophyte coverage is greater in smaller lakes (Duarte et al. 1986) leading to enhanced production and habitat composition. In the pelagic zone, too, small lakes have more complex thermal structure than large ones (Xenopoulos \& Schindler 2001).

Small lakes and ponds are important to the maintenance of regional biodiversity and stability. Small lakes have greater waterfowl species richness per unit area than large lakes (Elmberg et al. 1994). Small lakes and ponds promote enhanced regional biodiversity in aquatic birds, plants, amphibians and invertebrates because of low fish biomass and high richness and abundance of aquatic plants (Scheffer et al. 2006). Smaller lakes have a greater proportion of small non-game fish species such as the Cyprinidae (Matuszek et al. 1990); small non-game fish are often overlooked by fish management. Biomass size spectra show more negative coefficients in small lakes indicating a greater dominance of small, active organisms (Cyr \& Peters 1996). Figure 5 shows data on biodiversity in well-studied lakes analyzed by Dodson et al. (2000). The data indicate that small lakes contain many more species of virtually all taxa, per unit area, than do large lakes. Although no particular meaning should be attributed to the existence of such a correlation $\left(\mathrm{km}^{2}\right.$ appears in both axes), even moderate 


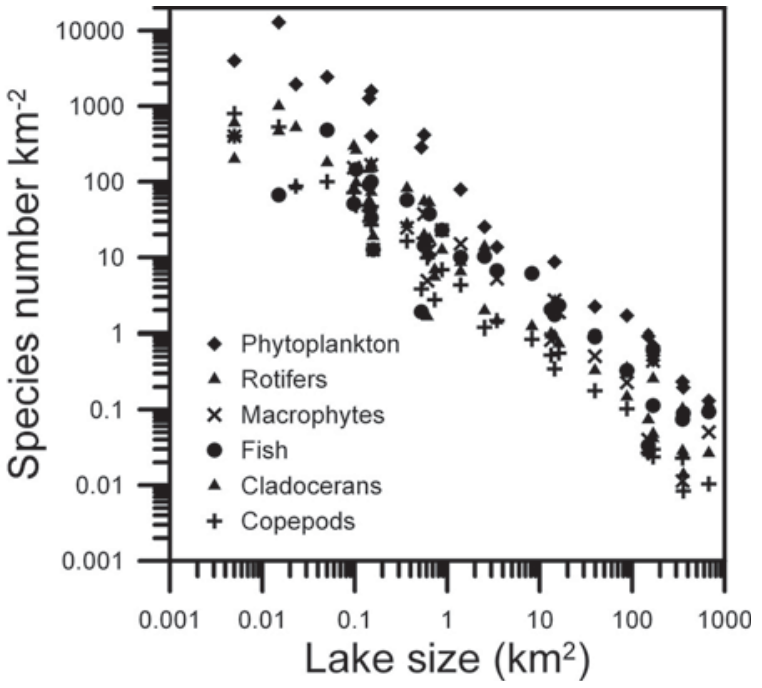

Figure 5. Species-richness per unit area of various aquatic taxa in lakes of different sizes (Data from Dodson et al. 2000). If individual lakes in the same region have slightly different community structure, the figure implies that small systems enhance regional biodiversity. Riqueza de especies por unidad de superficie de varios grupos taxonómicos en lagos de diferente tamaño (Datos de Dodson et al. 2000). Si los lagos individuales de una región tienen comunidades ligeramente diferentes, la figura indica que los sistemas pequeños aumentan la biodiversidad regional.

differences in community structure among small lakes and ponds suggest that higher regional biodiversity can be maintained by $100 \mathrm{~km}^{2}$ of small lakes than would be contributed by a single $100 \mathrm{~km}^{2}$ lake. This, plus the preference of recreational boaters for large lakes (Reed Andersen et al. 2000), may help explain why small lakes are known to be more resistant to invasion by exotic and nuisance species than are large ones (Winfield et al. 1998).

Small lakes and ponds are also known for high productivity. Fish productivity generally declines with increasing lake size, indicating that smallest lakes have highest production per unit area, often by several orders of magnitude (Rounsefell 1946, Hayes \& Anthony 1964, Youngs \& Heimbuch 1982, Downing et al. 1990) (Fig. 6). Lake size appears to act on biomass and fish-size distribution because after the effects of body mass and biomass are accounted for, fish production (per unit area) may be higher in larger lakes (Downing \& Plante 1993). Small lakes and ponds can be substantially more biologically active than large lakes.

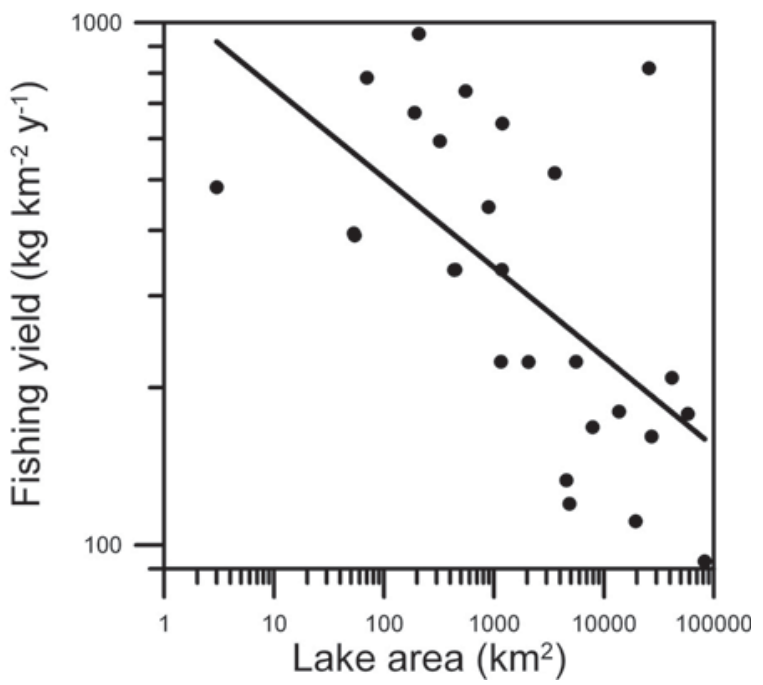

Figure 6. Fish yield and lake-size data summarized by Youngs \& Heimbuch (1982) from other sources (Ryder 1965, Oglesby 1977, Matuszek 1978). The solid line is a least-squares regression of the data showing the average trend in production with lake size $\left(r^{2}=0.39, n=27\right)$. Producción pesquera en relación con el tamaño del lago. Datos recogidos por Youngs \& Heimbuch (1982) de diversas fuentes (Ryder 1965, Oglesby 1977, Matuszek 1978). La línea sólida representa la regresión por mínimos cuadrados, mostrando la relación de la producción con el tamaño del lago $\left(\mathrm{r}^{2}=0.39, \mathrm{n}=27\right)$.

\section{Carbon-processing is intense in small lakes and ponds}

Information is beginning to emerge showing that carbon processing intensity is very great in small water bodies. Stable isotope analyses indicate that smaller lakes and ponds may be more heterotrophic than large ones, processing substantial amounts of terrestrial or external carbon (Post 2002). Dissolved organic carbon concentrations are therefore significantly negatively correlated with lake size (Xenopoulos et al. 2003). Surface $\mathrm{CO}_{2}$ concentrations are much higher in smaller lakes than large ones (Kelly et al. 2001). In another large data set taken from across Finland, $\mathrm{CO}_{2}$ concentrations and aerial $\mathrm{CO}_{2}$ evasion declined sharply with increasing lake size (Kortelainen et al. 2006). Oxygen concentrations tend to be lower in ponds and small lakes than in larger ones (Crisman et al. 1998), enhancing greenhouse gas (GHG) emissions and carbon sequestration. Potential methane emission is much 


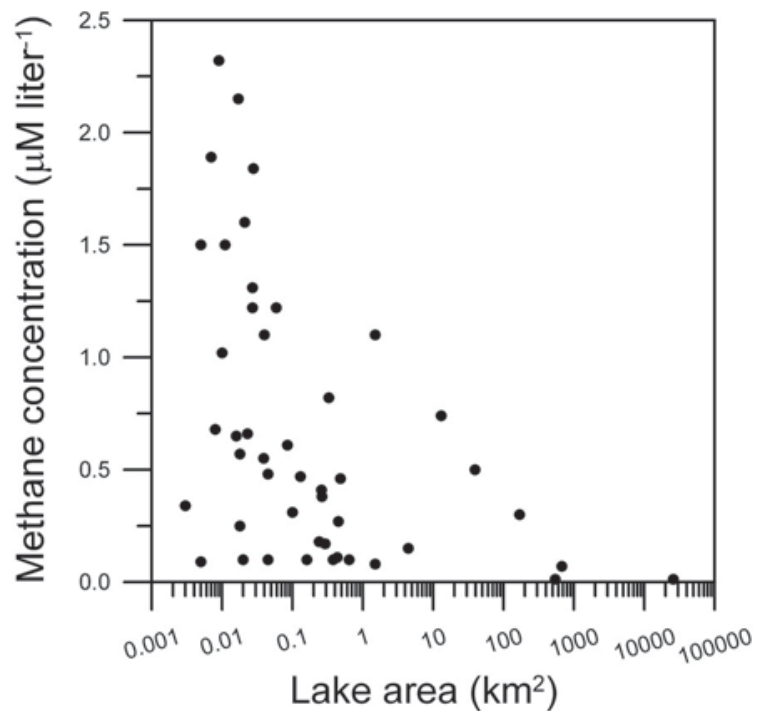

Figure 7. Measured methane concentrations in lakes from around the world related to the sizes of lakes. Data are from Bastviken et al. (2004). Concentraciónes de metano en lagos de diferentes partes del mundo, en relación con el tamaño de los lagos. (Datos de Bastviken et al. 2004).

greater in small lakes than large ones (Michmerhuizen et al. 1996). Using a data compilation from around the world, Bastviken et al. (2004) showed that concentrations of methane, and perhaps therefore losses to the atmosphere, are greatest in small lakes and ponds (Fig. 7). Low oxygen concentrations in small lakes (Crisman $e t$ al. 1998) and the relationship between low oxygen and elevated $\mathrm{N}_{2} \mathrm{O}$ (Knowles et al. 1981) suggest that $\mathrm{N}_{2} \mathrm{O}$ emissions from ponds and small lakes can be much higher than those of larger lakes. Rates of organic carbon sequestration per unit area in the sediments of small lakes has been suggested to be at least an order of magnitude higher than that of larger lakes (Dean \& Gorham 1998, Stallard 1998, Downing et al. 2008).

\section{Pond size, eutrophication, and carbon sequestration: some examples}

The global importance of an aquatic process or quantity depends, to some degree, upon the extent of the ecosystem type in the biosphere. Likewise, seemingly unimportant ecosystems, even those that cover only a small area of the land sur- face, can be important globally if the intensity of a process is extremely high. Even the smallest ponds are very abundant on Earth. A conservative estimate is that small agricultural ponds cover about 77,000 $\mathrm{km}^{2}$ worldwide (Downing et al. 2006, Downing \& Duarte 2009). Farm ponds and tanks appear to be increasing at rates from $0.7 \%$ per year to $60 \%$ per year in various regions as increasing pressure is put on agricultural lands to provide food for growing populations.

Previous analyses of roles of constructed lakes in important global rates like organic C burial (e.g., Cole et al. 2007) have calculated global deposition and carbon content of sediments derived mostly from large water bodies (Dendy \& Champion 1978, Mulholland \& Elwood 1982, Dean \& Gorham 1998, Stallard 1998). Because these data seemed limited and ignored the active and abundant small lakes and ponds on Earth, we recently used repeated bathymetric analyses and direct measures of sediment characteristics to estimate the likely rate of burial of organic $\mathrm{C}$ in the sediments of eutrophic lakes and impoundments (Downing et al. 2008). In the 40 lakes we studied (triangles, Fig. 8), we found that sediment organic carbon burial rates were higher than those assumed for fertile impoundments by previous studies and were much higher than those measured in natural lakes. Organic carbon burial ranged from a high of $17 \mathrm{~kg} \mathrm{C} / \mathrm{m}^{2} / \mathrm{y}$ to a low of $148 \mathrm{~g} \mathrm{C} / \mathrm{m}^{2} / \mathrm{y}$ and was significantly greater in small impoundments than large ones (Fig. 8).

These analyses suggest that median organic $\mathrm{C}$ sequestration in moderate to large impoundments may be double the rate assumed in previous analyses and exceeds rates of carbon sequestration found in any ecosystem in the world. Median areal $\mathrm{C}$ burial rates in these lakes were 10-times those seen in wetlands, 100-times those documented in tropical forests, 1000-times those assessed in tropical and boreal forests, and 10,000times those estimated for the world's oceans. Extrapolation suggests that each year, Earth's current moderately sized impoundments may bury 4-times as much $\mathrm{C}$ as the world's oceans. The world's farm ponds alone seem likely to sequester more organic carbon each year than the oceans and $33 \%$ as much as the world's rivers deliver to the sea. 


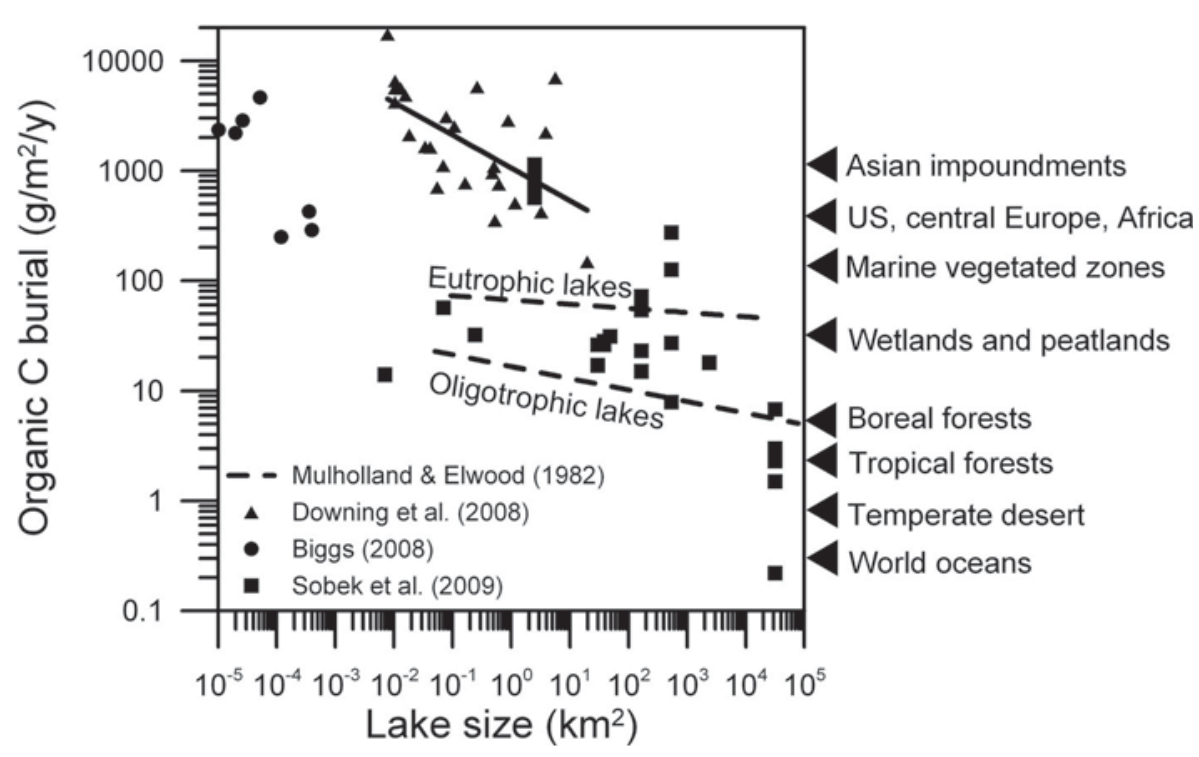

Figure 8. Sediment organic carbon burial rates compared among types of aquatic and terrestrial ecosystems. Data on oligotrophic and eutrophic lakes and impoundments in Asia, the United States, central Europe, and Africa are from Mullholland \& Elwood (1982). Data from Downing et al. (2008) are for lakes in an agriculturally eutrophic region of the Midwest United States; the solid line shows a least squares regression of these data. Observations made by Biggs (2008) are for small ponds in the United Kingdom. Data from Sobek et al. (2009) include a variety of lakes worldwide, including Lake Baikal at the extreme right of the graph. Terrestrial data are from Schlesinger (1997) and data on marine vegetated areas are from Duarte et al. (2005). Carbon burial in the world's oceans were calculated after Sarmiento \& Sundquist (1992) assuming the world's oceans have an area of 361 million $\mathrm{km}^{2}$. Arrows at right indicate median levels of carbon sequestration in diverse ecosystem types. Comparación de las tasas de entierro de carbono en diferentes tipos de ecosistemas acuáticos y terrestres. Los datos de lagos y embalses oligitróficos y eutróficos de Asia, Estados Unidos, Europa Central y Africa proceden de Mullholland \& Elwood (1982). Los datos de Downing et al. (2008) correponden a lagos en una región agrícola y eutrófica del Oeste Medio de Estados Unidos y la linea sólida representa la regresión por mínimos cuadrados de estos datos. Las observaciones de Biggs (2008) corresponden a pequeñas charcas del Reino Unido. Los datos de Sobek et al. (2009) incluyen una variedad de lagos de todo el mundo, con el lago Baikal en el extremo derecho del gráfico. Los datos terrestres son de Schlesinger (1997) y los de áreas marinas vegetadas de Duarte et al. (2005). El entierro de carbono en los océanos se ha calculado de acuerdo con Sarmiento \& Sundquist (1992) asumiendo que los océanos ocupan una superficie 361 millones de $\mathrm{km}^{2}$. Las flechas de la derecha indican la mediana de los niveles de secuestro de carbono en diversos tipos ecosistemas.

Eutrophication and landscape alteration may play important roles in determining $\mathrm{C}$ burial in lakes. $\mathrm{C}$ burial rates in eutrophic lakes are nearly an order of magnitude higher than those found in oligotrophic lakes of similar size (Fig. 8). Small lakes in agricultural regions (Downing et al. 2008) have very high rates of burial but are in the same range as the small UK ponds, impoundments around the world, and lakes with high sediment loads. For example, Lake Wohlen (Sobek et al. 2009), a mesotrophic, short water residence time (2 days) impoundment in the Aare River has $\mathrm{C}$ sequestration rates of $570-1140 \mathrm{~g} \mathrm{C}^{2} \mathrm{~m}^{2} / \mathrm{y}$. Therefore, it appears that extremely high rates of $\mathrm{C}$ burial are typical of small lakes, lakes with high rates of primary production due to eutroph- ication, and lakes receiving substantial loads of riverine or watershed-derived organic sediments. Small lakes and ponds make up around a third of the area of continental waters but have rates of $\mathrm{C}$ burial that exceed those of larger lakes by an order of magnitude or more. It is likely, therefore, that carbon sequestration by the world's small lakes and ponds dominates carbon burial by aquatic ecosystems. Because aquatic ecosystems seem to provide substantial carbon burial worldwide, ponds and small lakes may be the most important sites in the biosphere for organic carbon sequestration.

These findings should not be misconstrued to suggest that small lakes and ponds are perfect sinks for excess carbon. Small oligotrophic lakes may evade substantial allochthonous $\mathrm{C}$ as $\mathrm{CO}_{2}$ 
(Kelly et al. 2001, Kortelainen et al. 2006). Small lakes and ponds can be quite eutrophic so $\mathrm{CH}_{4}$ and $\mathrm{N}_{2} \mathrm{O}$ release may be substantial (Knowles et al. 1981, Michmerhuizen et al. 1996, Bastviken et al. 2004), exacerbating atmospheric problems. This analysis suggests, however, that an accurate view of the global carbon budget will be elusive unless small lakes and ponds are analyzed, understood, and considered.

\section{Global research needs for small aquatic ecosystems}

Global understanding of the role of small lakes and ponds in processes throughout the biosphere requires inventories of water bodies and knowledge of the important rates and processes they mediate (Downing 2009). There are three important steps. (1) We need to identify patternsin globally important quantities, rates, and processes, and understand how they covary with lake and pond characteristics. (2) We need to create scaling rules for these quantities, rates, and processes that will permit meaningful up-scaling to a global level. (3) Because society depends upon reliable global science, we need to derive numerical and statistical methods to ensure that global calculations are accurate and precise enough to be comparable to other global estimates. Accomplishment of these tasks will advance us substantially toward estimating human- and climate-mediated effects on the global role of small aquatic ecosystems.

Many variables are in need of global scaling. For example, understanding the conversions of carbon in small lakes and ponds is of very high priority, in order to contribute substantially to discussions of global climate change. Likewise, understanding of patterns in nutrients in these water bodies, as well as fluxes and conversions of important gasses (e.g., $\mathrm{N}_{2} \mathrm{O}, \mathrm{NH}_{x}$ ) and metals (e.g., $\mathrm{Hg}$ ), will improve global understanding of the role of small water bodies in global nutrient, gas, and toxin budgets. Remarkably, small lakes and ponds have not yet been integrated into global heat and water budgets so recognition of patterns in water and energy fluxes amongst aquatic systems is also important. Small aquatic ecosystems are disproportionately important sites for the production of food so it is important to evaluate global patterns in production.

We need to quantify and understand the role of small water bodies in the functioning of the biosphere. We do this by asking whether the quantity or process is large or small with respect to other types of ecosystems and whether we can make an estimate of that quantity or process that is well enough constrained to be reliable. These questions cause us to ascertain whether the process is likely great enough to justify a more accurate and precise answer and how likely we are to be able to define the answer more precisely. Therefore, much of this task is making estimates of biosphere-level rates and processes attributable to small lakes and ponds, comparing these to estimates made for other ecosystems, and refining and improving our estimates to yield more accurate and precise assessments of the global role of small aquatic systems.

\section{CONCLUSIONS}

Recently, limnologists and aquatic ecologists have discovered that aquatic ecosystems are much more plentiful in the biosphere than had been believed. This is especially true for small lakes and ponds because new analyses show that they cover as much or more area as large lakes. Because historical inventories underestimated the areal extent of small water bodies, limnologists have spent relatively little effort studying them so their importance to global and biosphere processes has been under-appreciated. Emerging studies now show that ponds and small lakes are more active in nearly every process than large lakes, terrestrial, and marine ecosystems. The large area covered by small aquatic systems and the intensity of activity mean that they may be among the most important ecosystems in the world. Considering the global carbon cycle, for example, ponds and small lakes sequester carbon at rates that are orders-of-magnitude greater than virtually all other global ecosystems. This compensates for the small area they cover relative to terrestrial and marine ecosystems, suggesting that carbon sequestration by ponds may 
be as great as or greater than that of forests, grasslands, and all the world's oceans. There are several knowledge gaps, however, including information on gas evasion and several other factors, so an active research agenda on small lakes and ponds is needed to bring them into the arena of global limnology and ecology. Work in such a high-priority arena is important to our science and careers but especially to understanding the role of small aquatic systems in the biosphere. Preliminary information suggests that they may be amongst Earth's most important and active environments.

\section{ACKNOWLEDGEMENTS}

I am grateful to the European Pond Conservation Network 2008 organizing committee for inviting me to address this important topic. I am also grateful to the NCEAS-ITAC group (authors of Downing et al. 2006, Cole et al. 2007), for advancing many of the subjects presented here. This work grew out of the ITAC Working Group supported by the National Center for Ecological Analysis and Synthesis, a Center funded by NSF (Grant DEB-94-21535), the University of California at Santa Barbara, and the State of California. This work was partially completed while I was on a sabbatical leave at Instituto Mediterraneo de Estudios Avanzados, Esporles, Mallorca, Islas Baleares, Spain, with the generous sponsorship of the Consejo Superior de Investigaciones Científicas of Spain. Other support was provided by the Wabana Lake Research Station.

\section{REFERENCES}

AMIEL, H.-F. 1893. Journal Intime. Macmillan. London, U.K. 402 pp.

BARTON, B. F. 1917. More power to you: fifty editorials from every week. The Century Company. New York, USA. 232 pp.

BASTVIKEN, D., J. J. COLE, M. L. PACE \& L. J. TRANVIK 2004. Methane emissions from lakes: Dependence of lake characteristics, two regional assessments, and a global estimate. Global Biogeochemical Cycles 18 10.1029/2004GB002238: 12.
BIGGS, J. 2008. Carbon uptake by UK ponds. Pond Conservation for Life in Freshwater. May 6, 2008. Oxford, UK. [http://www.pondconservation.org. uk/aboutus/ourwork/climatechangeandponds/carbonuptakebyUKponds, accessed in September, 2009]

BIN-LE, L., A. SAKODA, R. SHIBASAKI, N. GOTO \& M. SUZUKI. 2000. Modelling a global biogeochemical nitrogen cycle in terrestrial ecosystems for the evaluation of anthropogenic disturbance. Ecological Modelling, 135: 89-110.

BOLIN, B. 1983. The carbon cycle. In: The major biogeochemical cycles and their interactions, B. Bolin \&R. B. Cook (eds.): 980-987. John Wiley \& Sons, New York, USA.

CHAMEIDES, W. L. \& E. M. PERDUE. 1997. Biogeochemical Cycles: A Computer-Interactive Study of Earth System Science and Global Change. Oxford University Press. New York, USA. 240 pp.

CHRISTOPHERSON, R. W. 1994. Geosystems: An Introduction to Physical Geography, 2nd ed. Prentice Hall. Upper Saddle River, New Jersey, USA. 798 pp.

CLARKE, R. 1991. Water: the international crisis. Earthscan Publications Limited. London, UK. 224 pp.

CLOUD, P. \& A. GIBOR. 1970. The oxygen cycle. Scientific American, September 110-123.

COLE, J. J., Y. T. PRAIRIE, N. F. CARACO, W. H. MCDOWELL, L. J. TRANVIK, R. G. STRIEGL, C. M.DUARTE, P. KORTELAINEN, J. A.DOWNING, J. MIDDELBURG \& J. M. MELACK. 2007. Plumbing the global carbon cycle: integrating inland waters into the terrestrial carbon cycle. Ecosystems, 10: 171-184.

CONAN DOYLE, A. 1920. Adventures of Sherlock Holmes. A. L. Burt Company. New York, NY, USA. 307 pp.

CRISMAN, T. L., L. J. CHAPMAN \& C. A. CHAPMAN. 1998. Predictors of seasonal oxygen levels in small Florida lakes The importance of color. $\mathrm{Hy}$ drobiologia, 368: 149-155.

CYR, H. \& R. H. PETERS. 1996. Biomass size spectra and the prediction of fish biomass in lakes. Canadian Journal of Fisheries and Aquatic Sciences, 53: 685-697.

DEAN, W. E. \& E. GORHAM. 1998. Magnitude and significance of carbon burial in lakes, reservoirs, and peatlands. Geology, 26: 535-538.

DENDY, F. E. \& W. A. CHAMPION. 1978. Sediment deposition in U.S. reservoirs: summary of 
data reported through 1975. In: United States Department of Agriculture, Miscellaneous Publication: 84. Agricultural Research Service, United States Department of Agriculture, Washington, D.C.

DODSON, S. I., S. E. ARNOTT \& K. L. COTTINGHAM. 2000. The relationship in lake communities between primary productivity and species richness. Ecology, 81: 2662-2679.

DOWNING, J. A. 2009. Global limnology: Up-scaling aquatic services and processes to planet Earth. Verh. Internat. Verein. Limnol., 30: 1149-1166.

DOWNING, J. A., J. J. COLE, J. MIDDELBURG, R. G. STRIEGL, C. M. DUARTE, P. KORTELAINEN, Y. T. PRAIRIE \& K. A. LAUBE. 2008. Sediment carbon burial in agriculturally eutrophic impoundments over the last century. Global Biogeochemical Cycles, 22: 10.1029/2006GB002854.

DOWNING, J. A. \& C. M. DUARTE. 2009. Abundance and size distribution of lakes, ponds, and impoundments. In: Encyclopedia of Inland Waters, G. E. Likens (ed.): 469-478. Elsevier, Oxford, U.K.

DOWNING, J. A. \& C. PLANTE. 1993. Production of fish populations in lakes. Canadian Journal of Fisheries and Aquatic Sciences, 50: 110-120.

DOWNING, J. A., C. PLANTE \& S. LALONDE. 1990. Fish production correlated with primary productivity, not the morphoedaphic index. Canadian Journal of Fisheries and Aquatic Sciences, 47: 1929-1936.

DOWNING, J. A., Y. T. PRAIRIE, J. J. COLE, C. M. DUARTE, L. J. TRANVIK, R. G. STRIEGL, W. H. MCDOWELL, P. KORTELAINEN, N. F. CARACO, J. M. MELACK \& J. MIDDELBURG. 2006. The global abundance and size distribution of lakes, ponds, and impoundments. Limnology and Oceanography, 51: 2388-2397.

DUARTE, C. M., J. KALFF \& R. H. PETERS. 1986. Patterns in biomass and cover of aquatic macrophytes in lakes. Canadian Journal of Fisheries and Aquatic Sciences, 43: 1900-1908.

DUARTE, C. M., J. J. MIDDELBURG \& N. F. CARACO. 2005. Major role of marine vegetation on the oceanic carbon cycle. Biogeosciences, 2: 1-8.

ELMBERG, J., P. NUMMI, H. POYSA \& K. SJOBERG. 1994. Relationships between species number, lake size and resource diversity in assemblages of breeding waterfowl. Journal of Biogeography, 21: 75-84.

FRENEY, J. R., M. V. IVANOV \& H. RODHE. 1983. The sulphur cycle. In: The major biogeochemical cycles and their interactions, B. Bolin \& R. B. Cook (eds.): 56-61. John Wiley \& Sons, New York, USA.

FRIEDERICI, H. (ed.). 1978. Lichtenbergs Werke in einem Band. Aufbau-Verlag, Berlin, Germany. 378 pp.

GOODY, R. M. \& J. C. G. WALKER. 1972. Atmospheres. Prentice-Hall. Englewood Cliffs, NJ, USA. $160 \mathrm{pp}$.

GORHAM, E. 1958. The physical limnology of Great Britain: an epitome of the bathymetric survey of the Scottish Freshwater Lochs. Limnology and Oceanography, 3: 40-50.

GRAHAM, W. F. \& R. A. DUCE. 1979. Atmospheric pathways of the phosphorus cycle. Geochimica Cosmochimica Acta, 43: 1195-1208.

HALBFASS, W. 1914. Das Süsswasser der Erde (The freshwater of the Earth). Druch und Verlag von Philipp Reclam jun. Leipzig, Germany. 189 pp.

HAYES, F. R. \& E. H. ANTHONY. 1964. Productive capacity of North American lakes as related to the quantity and the trophic level of fish, the lake dimensions, and the water chemistry. Transactions of the American Fisheries Society, 93: 53-57.

HERDENDORF, C. E. 1984. Inventory of the morphometric and limnologic characteristics of the large lakes of the world. In: Technical Bulletin, 154. The Ohio State University Sea Grant Program.

HERMANN, W. 2006. Quantifying global exergy resources. Energy, 31: 1349-1366.

HINRICHSEN, D., B. ROBEY \& U. D. UPADHYAY. 1998. Solutions for a water-short world. Population Information Program, Center for Communication Programs, The Johns Hopkins School of Public Health. Baltimore, USA. 31 pp.

INTERGOVERNMENTAL PANEL ON CLIMATE CHANGE. 2001. Climate change 2001: the scientific basis. Cambridge University Press. Cambridge, UK. 881 pp.

KALFF, J. 2001. Limnology: inland water ecosystems. Prentice Hall. Upper Saddle River, NJ. USA. 592 pp.

KEELING, R. F., R. P. NAJJAR, M. L. BENDER \& P. P. TANS. 1993. What atmospheric oxygen measurements can tell us about the global carbon cycle. Global Biogeochemical Cycles, 7: 37-67.

KELLY, C. A., E. J. FEE, P. S. RAMLAL, J. W. M. RUDD, R. H. HESSLEIN, C. ANEMA \& E. U. SCHINDLER. 2001. Natural variability of carbon 
dioxide and net epilimnetic production in the surface waters of boreal lakes of different sizes. Limnology and Oceanography, 46: 1054-1064.

KIEHL, J. T. \& K. E. TRENBERTH. 1997. Earth's annual global mean energy budget. Bulletin of the American Meteorological Association, 78: 197208.

KNOWLES, R., D. R. S. LEAN \& Y. K. CHAN. 1981. Nitrous oxide concentrations in lakes: variations with depth and time. Limnology and Oceanography, 26: 855-866.

KORTELAINEN, P., M. RANTAKARI, J. T. HUTTUNEN, T. MATTSSON, J. ALM, S. JUUTINEN, T. LARMOLA, J. SILVOLA \& P. J. MARTIKAINEN. 2006. Sediment respiration and lake trophic state are important predictors of large $\mathrm{CO} 2$ evasion from small boreal lakes. Global Change Biology, 12 10.1111/j.13652486.2006.01167.x: 1554-1567.

LEHNER, B. \& P. DÖLL. 2004. Development and validation of a global database of lakes, reservoirs and wetlands. Journal of Hydrology, 296: 1-22.

LERMAN, A. 1988. Geochemical Processes-Water and Sediment Environments. Krieger Publishing Company. Malabar, Florida. USA. 492 pp.

MATUSZEK, J. E. 1978. Empirical predictions of fish yields of large North American lakes. Transactions of the American Fisheries Society, 107: 385394.

MATUSZEK, J. E., J. GOODIER \& D. L. WALES. 1990. The occurrence of Cyprinidae and other small fish species in relation to $\mathrm{pH}$ in Ontario lakes. Transactions of the American Fisheries Society, 119: 850-861.

MEYBECK, M. 1995. Global distribution of lakes. In: Physics and chemistry of lakes, A. Lerman, D. M. Imboden \&J. R. Gat (eds.): 1-35. SpringerVerlag, Berlin, Germany.

MICHMERHUIZEN, C. M., R. G. STRIEGL \& M. E. MCDONALD. 1996. Potential methane emission from north-temperate lakes following ice melt. Limnology and Oceanography, 41: 985-991.

MULHOLLAND, P. J. \& J. W. ELWOOD. 1982. The role of lake and reservoir sediments as sinks in the perturbed global carbon cycle. Tellus, 34: 490-499.

NELSON, D. M., P. TRÉGUER, M. A. BRZEZINSKI, A. LEYNAERT \& B. QUÉGUINER. 1995. Production and dissolution of biogenic silica in the ocean: Revised global estimates, comparison with regional data and relationship to biogenic sedimentation. Global Biogeochemical Cycles, 9: 359-372.
OERTLI, B., R. CÉRÉGHINO, A. HULL \& R. MIRACLE. 2009. Pond conservation: from science to practice. Hydrobiologia, 10.1007/s10750-0099891-9.

OGLESBY, R. T. 1977. Relationship of fish yield to lake phytoplankton standing crop, production, and morphoedaphic factors. Journal of the Fisheries Research Board of Canada, 34: 2271-2279.

PARETO, V. 1897. Cours d'économie politique. F. Rouge. 2 v. Lausanne, Switzerland. 426 pp.

POST, D. M. 2002. Using stable isotopes to estimate trophic position: models, methods, and assumptions. Ecology, 83: 703-718.

RAVEN, P. H., G. B. JOHNSON, J. B. LOSOS \& S. R. SINGER. 2004. Biology, Sixth ed. McGrawHill Higher Education. Boston, USA. 1238 pp.

REED ANDERSEN, T., E. M. BENNETT, B. S. JORGENSEN, G. LAUSTER, D. B. LEWIS, D. NOWACEK, J. L. RIERA, B. L. SANDERSON \& R. STEDMAN. 2000. Distribution of recreational boating across lakes: Do landscape variables affect recreational use? Freshwater Biology, 43: 439448.

RICHEY, J. E. 1983. The phosphorus cycle. In: The major biogeochemical cycles and their interactions, B. Bolin \& R. B. Cook (eds.): 51-56. John Wiley \& Sons. New York, USA.

ROSSWALL, T. 1983. The nitrogen cycle. In: The major biogeochemical cycles and their interactions, B. Bolin \& R. B. Cook (eds.): 46-50. John Wiley \& Sons. New York, USA.

ROUNSEFELL, G. A. 1946. Fish production in lakes as a guide for estimating production in proposed reservoirs. Copeia, 1: 29-40.

ROY, R. N., R. V. MISRA, J. P. LESSCHEN \& E. M. SMALING. 2003. Assessment of soil nutrient balance: approaches and methodologies. Food and Agriculture Organization of the United Nations. Rome, Italy. 98 pp.

RYDER, A. 1965. A method for estimating the potential fish production of north-temperate lakes. Transactions of the American Fisheries Society, 94: 214-218.

SARMIENTO, J. L. \& E. T. SUNDQUIST. 1992. Revised budget for the oceanic uptake of anthropogenic carbon dioxide. Nature, 356: 589-593.

SCHEFFER, M., G. J. VAN GEEST, K. ZIMMER, M. G. BUTLER, M. A. HANSON, S. DECLERCK, L. DE MEESTER, E. JEPPESEN \& M. SONDERGAARD. 2006. Small habitat size and 
isolation can promote species richness: secondorder effects on biodiversity in shallow lakes and ponds. Oikos, 112: 227-231.

SCHIMEL, D. S., I. ENTING, M. HEIMANN, T. M. WIGLEY, D. RAYNAUD, D. ALVES, \& U. SIEGENTHALER. 1995. $\mathrm{CO}_{2}$ and the carbon cycle. In: Climate Change : Radiative Forcing of Climate Change and An Evaluation of the IPCC IS92 Emission Scenarios, J. T. Houghton (ed.): 35-71. Cambridge University Press, Cambridge, UK.

SCHLESINGER, W. H. 1997. Biogeochemistry: an analysis of global change. Academic Press. San Diego, California, USA. 588 pp.

SCHUILING, R. D. 1977. Source and composition of lake sediments. In: Interaction between sediments and fresh water: Proceedings of an international symposium held at Amsterdam, the Netherlands, September 6-10, 1976, H. L. Golterman (ed.): 12-18. Dr. W. Junk B.V., Wageningen, Netherlands.

SEINFELD, J. H. \& S. N. PANDIS. 1998. Atmospheric chemistry and physics: from air pollution to climate change. Wiley and Sons. New York, USA. 1326 pp.

SHIKLOMANOV, I. A. \& J. C. RODDA. 2003. World water resources at the beginning of the twenty-first century. Cambridge University Press. Cambridge, U.K. 452 pp.

SOBEK, S., E. DURISCH-KAISER, R.ZURBRÜGG, N. WONGFUN, M. WESSELS, N. PASCHE \& B. WEHRLI. 2009. Organic carbon burial efficiency in lake sediments controlled by oxygen exposure time and sediment source. Limnology and Oceanography, 54: 2243-2254.

STALLARD, R. F. 1998. Terrestrial sedimentation and the $\mathrm{C}$ cycle: coupling weathering and erosion to carbon storage. Global Biogeochemical Cycles, 12: 231-237.

STRAŠKRABA, M. 1980. The effects of physical variables on freshwater production: analyses based on models. In: The functioning of freshwater ecosystems, E. D. Le Cren \&R. H. LoweMcConnell (eds.): 13-84. International Biological Programme. Cambridge University Press, Cambridge, U.K.

THIENEMANN, A. 1925. Die Binnengewässer Mitteleuropas (The inland water of Central Europe). E. Schweitzerbart'sche Verlagsbüchhandlung. Stuttgart, Germany. 255 pp.

THORNELOE, S. A., K. A. WEITZ, S. R. NISHTALA, S. YARKOSKY \& M. ZANNES. 2002.
The impact of municipal solid waste management on greenhouse gas emissions in the United States. Journal of Air and Waste Management Association, 52: 1000-1011.

TRANVIK, L. J., J. A. DOWNING, J. B. COTNER, S. A. LOISELLE, R. G. STRIEGL, T. J. BALLATORE, P. J. DILLON, K. FINLAY, K. FORTINO, L. B. KNOLL, P. KORTELAINEN, T. KUTSER, S. LARSEN, I. LAURION, D. M. LEECH, S. L. MCCALLISTER, D. M. MCKNIGHT, J. M. MELACK, E. OVERHOLT, J. A. PORTER, Y. T. PRAIRIE, W. H. RENWICK, F. ROLAND, B. S. SHERMAN, D. W. SCHINDLER, S. SOBEK, A. TREMBLAY, M. J. VANNI, A. M. VERSCHOOR, E. VON WACHENFELDT \& G. A. WEYENMEYER. 2009. Lakes and impoundments as regulators of carbon cycling and climate. Limnology and Oceanography, 54: 2298-2314.

TRÉGUER, P., D. M. NELSON, A. J. V. BENEKOM, D. J. DEMASTER, A. LEYNAERT \& B. QUÉGUINER. 1995. The silica balance in the world ocean: a reestimate. Science, 268: 375-379.

UNITED STATES CLIMATE CHANGE SCIENCE PROGRAM. 2003. Strategic plan for the U.S. climate change science program. United States Government Printing Office. Washington, DC. 364 pp.

VIDONDO, B., Y. T. PRAIRIE, J. M. BLANCO \& C. M. DUARTE. 1997. Some aspects of the analysis of size spectra in aquatic ecology. Limnology and Oceanography, 42: 184-192.

WALKER, J. C. G. 1980. The Oxygen Cycle. In: The Natural Environment and the Biogeochemical Cycles. O. Hutzinger (ed.): 87-104. Springer-Verlag. Berlin, Germany.

WEISSERT, H. 2000. Global change: deciphering methane's fingerprint. Nature, 406: 356-357.

WETZEL, R. W. 1990. Land-water interfaces: metabolic and limnological regulators. Verh. Internat. Verein. Limnol., 24: 6-24.

WETZEL, R. W. 2001. Limnology: lake and river ecosystems. Academic Press. San Diego, CA, USA. 1006 pp.

WINFIELD, I. J., R. ROESCH, M. APPELBERG, A. KINNERBACK \& M. RASK. 1998. Recent introductions of the ruff (Gymnocephalus cernuus) to Coregonus and Perca Lakes in Europe and an analysis of their natural distributions in Sweden and Finland. Journal of Great Lakes Research, 24: 235-248.

WINTER, T. C., J. W. HARVEY, O. L. FRANKE \& W. M. ALLEY. 1998. Ground water and surface 
water, a single resource. United States Geological Survey. 79 pp.

XENOPOULOS, M. A., D. M. LODGE, J. FRENTRESS, T. A. KREPS, S. D. BRIDGHAM, E. GROSSMAN \& C. J. JACKSON. 2003. Regional comparisons of watershed determinants of dissolved organic carbon in temperate lakes from the Upper Great Lakes Region and selected regions globally. Limnology and Oceanography,
48: 2321-2334.

XENOPOULOS, M. A. \& D. W. SCHINDLER. 2001. The environmental control of near surface thermoclines in boreal lakes. Ecosystems, 4: 699707.

YOUNGS, W. D. \& D. G. HEIMBUCH. 1982. Another consideration of the morphoedaphic index. Transactions of the American Fisheries Society, 111: 151-153. 